\section{HSE}

Historia Social y de la Educación

Social and Education History
Hipatia Press

www.hipatiapress.com

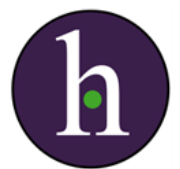

Instructions for authors, subscriptions and further details:

http://hse.hipatiapress.com

\title{
South Asian Immigration and Education in the U.S.: Historical and Social Contexts
}

Zaynah Rahman ${ }^{1}$, Susan J. Paik ${ }^{1}$

1) Claremont Graduate University (United States)

Date of publication: February 23rd, 2017

Edition period: February 2017 - June2017

To cite this article: Rahman, Z., \& Paik, S.J. (2017). South Asian immigration and education in the U.S.: Historical and Social Contexts. Social and Education History, 6(1), 26-52. doi:10.17583/hse.2017.2393

To link this article: http://dx.doi.org/10.17583/hse.2017.2393

\section{PLEASE SCROLL DOWN FOR ARTICLE}

The terms and conditions of use are related to the Open Journal System and to Creative Commons Attribution License (CC-BY). 


\section{South Asian Immigration and Education in the U.S.: Historical and Social Contexts}

Zaynah Rahma

Claremont Graduate University

(United States)
Susan J. Paik

Claremont Graduate University

(United States)

\section{Abstract}

This article examines the historical and social contexts of South Asian immigration and their current socioeconomic and educational outcomes in the United States. Based on an adapted model of incorporation and literature review, this historical analysis examines government policies, societal reception, co-ethnic communities, as well as other barriers and opportunities of three immigration waves before and after the Immigration Act of 1965 . The study reveals the modes of incorporation differed for each immigrant wave as well as subsequent socioeconomic and educational outcomes within the South Asian community. Before 1965, the earliest migrants had several barriers to incorporation coupled with government and societal hostility. After 1965, South Asians began immigrating under more favorable or neutral modes of incorporation. They were also more wealthy, educated, fluent in English, and had professional skills. While the majority of South Asians today represent this demographic composition, a rising subgroup of immigrants arriving under differential circumstances since the 1980s are facing more unique challenges within this community.

Key words: South Asian American, immigration history, co-ethnic community, modes of incorporation, educational outcomes 


\section{Inmigración del Sud de Asia y Educación en USA: Contextos Histórico y Sociales}

Zaynah Rahma

Claremont Graduate University

(United States)
Susan J. Paik

Claremont Graduate University

(United States)

\section{Resumen}

Este artículo examina los contextos históricos y sociales de la inmigración del sur de Asia y sus actuales resultados socioeconómicos y educativos en los Estados Unidos. Basado en un modelo adaptado de integración y en la revisión de literatura, este análisis histórico examina políticas gubernamentales, la recepción social, comunidades co-étnicas, así como otras barreras y oportunidades de tres olas migratorias antes y después de la Ley de Inmigración de 1965. El estudio revela los modos de integración diferenciados para cada una de las olas migratorias así como sus subsecuentes resultados socioeconómicos y educativos dentro de la comunidad sudasiática. Antes de 1965, las primeras personas inmigrantes encontraron diversas barreras para la inclusión junto a la hostilidad gubernamental y social. Después de 1965, las personas sudasiáticas empezaron a inmigrar bajo condiciones de integración más favorables o neutrales. También eran más ricas, educadas, con un inglés más fluido, y con habilidades profesionales. Si bien la mayoría de personas surasiáticas representan actualmente esta composición demográfica, un creciente subgrupo de inmigrantes que están llegando bajo circunstancias diferentes desde la década de los 80 se enfrentan a retos especialmente difíciles dentro

de

esta

comunidad.

Palabras clave: inmigración del sur de Asia, historia de la inmigración, comunidad coétnica, modelos de integración, resultados educativos 


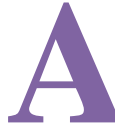

sian Americans have recently been reported as the fastest growing, most educated, and wealthiest racial group in the United States (Pew Research Center, 2012, p. 3). South Asians, in particular, saw one of the highest rates of academic and socio-economic growth in the US. They have also recently gained visibility through notable individuals, such as actors Kal Penn, Mindy Kaling, and Aziz Ansari, authors Jhumpa Lahiri and Deepak Chopra, and politician Bobby Jindal. While South Asian Americans overall have high professional skills, income levels, and educational attainment rates, polarization in outcomes and experiences do exist within this community today. For example, newer immigrants in the urban ethnic enclaves often struggle in blue-collar jobs as taxi drivers, store clerks, or small motel operators. Additionally, South Asians across the board have been cast under post-9/11 discrimination as people resembling brownskinned Muslims (Verma, 2008). Consequently, they have faced more racism and discrimination within society and schools in present day.

The monolithic view of Asian Americans has been notably challenged by scholars over the past decade. In the same vein, South Asians also have diversity within their own ethnic community (i.e., Indian, Pakistani, Bangladeshi, etc.). Although many South Asians are successful in the US, there is a growing group of immigrants that struggles upon arrival. There is limited research on the successes or struggles of this growing South Asian community. In many cases, they are also completely neglected from inclusion in studies examining Asian Americans in general (Blair \& Qian, 1998; Teranishi, Ceja, Antonio, Allen, \& McDonough, 2004).

In order to understand the diversity within this ethnic community and their current socioeconomic and educational outcomes, it is important to understand the historical and social experiences of South Asian American communities. An examination of immigration factors such as government policies, societal reception, co-ethnic communities, settlement patterns, class status, education, occupation, language ability and time of arrival to the US would help to understand overall and differential outcomes for this ethnic group.

Therefore, the purpose of this article is to better understand the historical and social contexts of South Asian groups in terms of their present-day educational and socioeconomic outcomes in the US. This article focuses on 
the three largest ethnic groups, Indians, Pakistanis, and Bangladeshis; other groups were not included due to the dearth of data and scholarly literature. This article will: 1) utilize the Asian American modes of incorporation framework (Paik, Kula, Saito, Rahman, \& Witenstein, 2014) to understand the immigration experiences of South Asian communities; 2) present current demographic, occupational and educational data on South Asians, 3) provide historical context on three waves of South Asian immigration to the US both before and after the Immigration Act of 1965, and 4) discuss how past immigration experiences link to present-day ethnic communities and their educational trends. The article will conclude with how this historical analysis can help inform practice and policy recommendations for South Asian American communities.

\section{Theoretical Framework: Modes of Incorporation}

The theoretical framework is based on the "Asian American modes of incorporation" by Paik et al. (2014), adapted from Portes and Rumbaut's (1990, 2001) early work on modes of incorporation, to examine the immigration experiences of Asian communities in the US and their impact on later group outcomes (e.g., education). The framework consists of four key factors that affect immigrant experiences in terms of adaptation to the host country: a) Government Policy, b) Societal Reception, c) Co-ethnic Communities, and d) Other Barriers \& Opportunities. The first three factors derive from Portes and Rumbaut's original model. The fourth factor was added by Paik et al. (2014) to examine how time of arrival; location and settlement patterns; class status, occupation, and educational level; and language abilities affected immigrant experiences. Each of these four factors is categorized as positive, negative, or neutral experiences, as described below. The adapted modes of incorporation framework will be used to understand how current educational and occupational trends are impacted by the South Asian immigration trajectory.

\section{Government Policy}

Under this framework, government policy is characterized as "receptive", "indifferent", or "hostile" towards immigration for ethnic groups. Receptive 
30 Rahman \& Paik - South Asian Immigration \& Education in the U.S.

policy encourages immigration with assistance or incentives, indifferent policy allows legal immigration without added assistance, and hostile policy blocks immigration.

\section{Societal Reception}

Societal reception refers to the public perception and prejudices against immigrant populations, which often influence the types of employment and other opportunities for new immigrants. Societal reception by immigrants is characterized as "prejudiced," "neutral" or "unprejudiced."

\section{Co-ethnic Communities}

Portes and Rumbaut $(1990,2001)$ described co-ethnic communities as resource networks, rather than social networks, within each ethnic group that provides newcomers with access to information, resources and socioeconomic opportunities. Co-ethnic communities are characterized as "weak", "strong", or "dispersed" based on the concentration or disbursement of laborers, professionals, or entrepreneurs. A community is "strong" if the ethnic group is comprised mostly of professionals and highly educated individuals living in areas of high ethnic concentration. A community is "dispersed" if its group members are skilled professionals, but dispersed geographically because of their low reliance on their ethnic communities for resources. And a community is considered "weak" if its members live in areas of high ethnic concentration, but consist primarily of less skilled individuals.

\section{Other Barriers and Opportunities}

Paik et al. (2014) included six factors under "Other Barriers and Opportunities", which are critical to understanding immigration experiences for Asian immigrants: a) time of arrival (pre-or post-1965; marked by the Immigration Act legalizing immigration from Asia, thereby enabling a more favorable environment for immigrant groups); b) settlement patterns (coastal or inland; coastal settlements offered easier access to co-ethnic networks); c) class status/SES (higher or lower; higher status acceded greater benefits); d) 
occupation (professional or working class; professional and entrepreneurial fields produced better prospects); e) education level (higher educational attainment lead to greater opportunity); and f) English language ability (greater English ability enabled easier acculturation to the host country). These factors play an important role in the types of opportunities or barriers experienced by Asian American groups.

\section{South Asian Communities in the US: Current Demographic, Educational, and Occupational Data}

South Asian Americans have roots from the Indian subcontinent, including India, Pakistan, Bangladesh, Sri Lanka, Nepal, Bhutan and the Maldives (Sandhu \& Madathil, 2008). According to the US Census, in 2010 the South Asian population was estimated to be about 3.86 million, reflecting over $20 \%$ of the Asian American population (US Census, 2010). They were also the fastest growing among all Asian Americans (Asian American Center for Advancing Justice 2011). This study will focus on immigrants from India, Pakistan, and Bangladesh, because these countries have sent the largest numbers of immigrants to the United States, and much of the available data and scholarly literature pertains to them.

While migration from all three countries has steadily increased, Indians make up the highest US population of South Asians. Indians account for just over $80 \%$ of South Asians and are the third-largest Asian American group in the US behind Chinese and Filipino Americans. The 2010 Census statistics show the Indian population in the US grew from 1,899,599 in 2000 to $3,183,063$ in 2010; a growth rate of about 68\% (US Census, 2010). Pakistanis numbered at over 409,000 and Bangladeshis at 147,000 in 2010. A notable fact about the South Asian population is that they represent mostly new immigrants. Over three-quarters arrived after 1980 and are therefore mostly foreign-born (US Government Accountability Office, 2007).

Today, these South Asians live primarily in metropolitan areas on the East and West coasts. The largest South Asian communities are located in California, New York, New Jersey and Texas. Indians and Pakistanis are also populous in Illinois, while Bangladeshis have sizable populations in Michigan (US Census, 2010). Table 1 presents a visual description of the US South Asian population from 2010 Census data: 
32 Rahman \& Paik - South Asian Immigration \& Education in the U.S.

Table 1

South Asian American 2010 Demographic Data

\begin{tabular}{llll}
\hline $\begin{array}{l}\text { Ethnic } \\
\text { group }\end{array}$ & $\begin{array}{l}\text { Population } \\
\text { (alone or in any } \\
\text { combination) }\end{array}$ & $\begin{array}{l}\text { \% of AA } \\
\text { population } \\
(17,320,856)\end{array}$ & Most populous states \\
\hline Indian & $3,183,063$ & $18.4 \%$ & CA, NY, NJ, TX, IL \\
Pakistani & 409,163 & $2.4 \%$ & NY, TX, CA, IL, NJ, VI \\
Bangladeshi & 147,300 & $0.85 \%$ & NY, CA, TX, MI, NJ \\
\hline
\end{tabular}

Source: 2010 US Census Bureau, 2010 American Community Survey,

Race/ethnicity population alone or in any combination.

In terms of educational trends, South Asians generally exhibit high K-12 and post-secondary achievement. Table 2 shows that all three South Asian groups have more bachelors and graduate degrees than Whites, Asians, and the overall US population. Indians lead with $38.8 \%$ earning graduate degrees (US Census, 2010). Not only are many South Asian Americans completing bachelors and graduate education, some scholars have found that the more successful Asian American groups are also overrepresented at first-tier universities (Sakamoto, Goyette, \& Kim, 2009; Xie \& Goyette, 2003). Regarding K-12 achievement, South Asians have high grades compared to Whites and other Asians. Kao's use of (1995) data from the National Education Longitudinal Study of 1988 (NELS:88) found higher academic performance of South Asians, Chinese, and Korean eighth graders compared to Whites and other Asian groups from comparable family backgrounds. Vartanian et al. (2007) examined Japanese, Chinese, Korean, Filipino, Southeast Asian, and South Asian populations in NELS:88 data and found that South Asian students had the highest GPA amongst them. On the other hand, some qualitative studies warn the children of a recent subgroup of South Asian immigrants arriving since the mid-1980s face difficulty in adjustment to school and performance in school (Bhattacharya, 2000; Bhattacharya \& Schoppelrey, 2004; National Asian Pacific American Community Development Data Center, 2005; Verma, 2008; Wright, 2007). This trend has not yet affected the achievement statistics for South Asians overall, but there is a possibility of lowered achievement levels in the future. 
Table 2

Educational Attainment of South Asian Americans in 2010

\begin{tabular}{llllll}
\hline & $\begin{array}{l}\text { Less than } \\
\text { high school } \\
\%\end{array}$ & $\begin{array}{l}\text { High } \\
\text { school } \\
\text { graduate } \%\end{array}$ & $\begin{array}{l}\text { Some } \\
\text { college or } \\
\text { A.A. \% }\end{array}$ & $\begin{array}{l}\text { Bachelor's } \\
\text { degree } \%\end{array}$ & $\begin{array}{l}\text { Graduate } \\
\text { degree \% }\end{array}$ \\
\hline Total & 14.4 & 28.5 & 28.9 & 17.7 & 10.4 \\
White & 12.3 & 29.0 & 29.3 & 18.6 & 10.9 \\
Asian & 14.6 & 16.0 & 19.6 & 29.6 & 20.3 \\
Indian & 9.0 & 9.2 & 11.0 & 32.0 & 38.8 \\
Bangladeshi & 16.7 & 16.5 & 18.2 & 25.9 & 22.8 \\
Pakistani & 13.3 & 17.4 & 16.1 & 30.1 & 23.1 \\
\hline
\end{tabular}

Source: 2010 US Census Bureau, 2010 American Community Survey, Population 25 years and over, Race/ethnicity alone population.

Occupational trends appear to be bi-modal for South Asians. Many have careers in the technology and medical fields, yet several within the community are also employed in lower-wage jobs as cashiers, taxi workers, and restaurant workers (SAALT, 2012). Indians tend to occupy the management/professional occupations while Bangladeshis and Pakistanis are in sales/office. Additionally, Indians have a much higher average income than the national average and in comparison to other non-Asian and Asian subgroups. For instance, from 2005 data the US Government Accountability Office (2007) estimated the average income of Asian Indians at $\$ 65,000$, Whites at \$52,097, African Americans at \$36,025, Hispanics at \$32,106, and Chinese (the second highest average income among Asian Americans) at $\$ 56,000$. Bangladeshis and Pakistanis usually have lower income levels than Indians.

\section{South Asian Immigration History}

South Asian immigration to the US occurred in three major waves, beginning in the mid-nineteenth century. To better understand the story of this migration, it is important to be familiar with the historical context of the Indian subcontinent. India, Pakistan and Bangladesh once constituted one big nation under British rule, called India. In 1947, when British rule ended, 
the country was divided into the independent countries of India and Pakistan (Bhattacharya \& Schoppelrey, 2004). The majority of Indians were Hindu while Bangladeshis and Pakistanis were predominantly Muslim. In 1971, another division occurred - the eastern half of Pakistan became independent and gave birth to Bangladesh. This context explains why much of the historical literature on South Asian immigration to the US discusses only migration from 'India'.

\section{First Wave}

In the earlier years, immigrant numbers from South Asia were small and estimated in the few thousands. The first wave of immigrants arrived between 1897 and 1924, and consisted of mainly illiterate male Sikh and Muslim peasants from the Punjab province in India (Bhattacharya \& Schoppelrey, 2004; Leonard, 1997). Like the East Asians, they were looking for better economic opportunities in the US and came to fulfill the cheap labor needs of rail, agricultural and lumber industries in California, Oregon and Washington. There was also a much smaller number of Muslim men migrating from the Bengal region of India (what is present day Bangladesh) working as peddlers in New York, New Jersey, Maryland and New Orleans (Bald, 2015). This early wave of immigration was marked by great antiAsian, highly racist sentiment. The South Asian immigrants were not allowed to own land, gain citizenship rights, bring their spouses and other family members to the US, or even marry local white American women (Leonard, 1997; Purkayastha, 2005). Soon, a number of immigration exclusion acts were established to curtail population growth in the US for many Asian groups. For example, the Immigrant Act of 1924 barred the entry of all Asian groups, including Indians. Consequently, the population of Indian immigrants became smaller. Some of the men married Mexican women and created new ethnic communities, such as the Punjabi-Mexicans. Similarly, the Bengali Muslim men in the East Coast married Creole, Puerto Rican, and African American women and integrated into some of America's neighborhoods of color (e.g., New York's Bengali Harlem) (Bald, 2015). 


\section{Second Wave}

In 1965, US immigration laws were changed to accommodate labor market needs. The Immigration and Nationality Act of 1965 marked the beginning of the second wave of immigration (Leonard, 1997; Sandhu \& Madathil, 2008). This wave of immigrants was drawn from all over India and from Pakistan, Bangladesh, Sri Lanka and Nepal. The new immigration laws gave preference to highly skilled professionals, such as scientists, doctors and engineers, and their families (Bhattacharya \& Schoppelrey, 2004; Purkayastha, 2005; Saran, 2007). Consequently, a large percentage of South Asians who migrated after 1965 have been college educated, urban middle class professionals, or students seeking advanced university training. Generally, these individuals achieved financial success, gained US citizenship, and were allowed to bring family members with them. They moved into the white suburban neighborhoods of America and assimilated into the dominant host society.

There has been a continuous and steady stream of students coming to the US for higher education; more than half of all Indian immigrants who changed their status in the $1950 \mathrm{~s}$ and $60 \mathrm{~s}$ to resident alien had arrived initially as students (Leonard, 1997). In the Institute of International Education's (2010) Open Doors report, its annual statistical survey of international students in US higher education found that in 2009-10, India sent the second largest group of foreign students to the US $(104,897$ students; $15 \%$ of all international students). The issue of "brain drain" was becoming a concern to South Asian countries with an estimated one-fourth of graduates of Indian medical colleges coming to the US annually in the mid to late 1900s (Leonard, 1997). But it did not lead to any significant emigration restrictions by the South Asian countries due to unemployment problems in the home countries and the welcomed influx of foreign-currency remittances sent to the home countries by emigrants.

\section{Third Wave}

During the 1980s, the third wave of immigration brought a significant demographic shift, increasing polarization within the South Asian immigrant community. Many second-wave and well-established South Asian Americans 
were sponsoring their family members through the Family Reunification Act (Sandhu \& Madathil, 2008). Thus, while skilled professionals and students continued to arrive, a subgroup of immigrants who were less educated and less fluent in English than their predecessors came to the US through diversity visas and family reunification criteria. Even those with foreign post-secondary credentials often found they were unaccepted in the US. These individuals settled into urban ethnic enclaves and worked mostly bluecollar jobs as taxi drivers, store clerks, or small motel operators, or owned small businesses (Bhattacharya \& Schoppelrey, 2004; Verma, 2008). More Bangladeshis and Pakistanis began migrating in this third wave of immigration and thus tend to have lower socioeconomic statuses than their Indian counterparts (National Asian Pacific American Community Development Data Center, 2005).

\section{Modes of Incorporation, Barriers and Opportunities for South Asians}

This section uses the modes of incorporation framework (Paik et al., 2014) to review the literature and analyze the immigration experiences of South Asian Americans. Taking their history into account, government policies, societal reception, and co-ethnic communities will be discussed in positive, negative or neutral experiences (as described earlier). Settlement patterns, class and occupational levels, education, and English fluency will also be discussed as additional barriers or opportunities for each immigration wave.

\section{Government Policy}

Before the mid-1900s, government policies were fairly hostile towards South Asian immigrants. Both federal and state laws restricted these immigrants from land ownership, citizenship rights, bringing family members, and marrying white women (Leonard, 1997; Purkayastha, 2005). For example, The California Alien Land Act of 1913 prevented all immigrants ineligible for citizenship to own agricultural land. Then in 1917 and 1924, US immigration laws barred entry to all Asian immigrants. It wasn't until 1946 when South Asians began seeing signs of favorable change in the decades of discrimination in US immigration policy. The 1946 LuceCellar Act initiated this change by accepting 200 South Asians into the US 
annually and allowing their naturalization. Once citizens, they could bring relatives to the US. Then in 1965, the hallmark US Immigration and Nationality Act legalized and increased immigration for South Asians on the basis of preferred skills or family reunification (Purkayastha, 2005). With this receptive policy, education and work opportunities became readily available in engineering, medicine, and science, encouraging thousands of highly educated and skilled South Asians to emigrate to the US.

Since the 1980s, a subgroup of lower-skilled South Asian immigrants began arriving under the diversity visa and family re-unification criteria. While many second wave immigrants held US citizenship, the newer immigrants held temporary visas or sought political asylum. Some studies indicate this subgroup is facing difficulty adapting to the US (Bhattacharya \& Schoppelrey, 2004; Chhaya Community Development Corporation, 2012). These individuals often find their foreign degrees and professional qualifications are rejected in the US. Hence, they face competition for limited jobs and are relegated to blue collar work. Government policies and attitudes have been indifferent as there is very little support for these newcomers. Since 9/11, US immigration scrutiny has also fallen heavily on South Asians entering and living in the US, demonstrating the most recent form of government hostility towards an Asian group (Verma, 2008). Certain government policies and practices have threatened their civil liberties, such as the Patriot Act and Special Registration program (South Asian Network, 2016). The community has also been targeted for FBI surveillance and investigations, detentions and deportations. Additionally, the wait for citizenship and employment visas has been prolonged due to post 9/11 antiimmigrant legislature (Verma, 2008).

\section{Societal Reception}

American societal reception of South Asian immigrants shifted with each wave. Perception has shifted from viewing the early migrants as "the yellow peril" to the model minority and now back to seeing South Asians as backwards and dangerous (Verma, 2008, p. 19). The first wave of immigrants was perceived as illiterate and backward and heavily discriminated against in the farming communities. Their arrival in California was portrayed by American media as "a tide of turbans" flowing into the 
country (Bald, 2015; Purkayastha, 2005, p. 17; Verma, 2008, p. 3). This prejudiced perception essentially discriminated against South Asians, subjugating the immigrants to menial jobs with unfair rules in their workplace. Their arrival was also met with white citizen's groups and labor unions stacked against them as Chinese and Japanese migration had been targeted as well (Bald, 2015).

The South Asians who migrated to the US after 1965 were well-educated, English-proficient, highly qualified professionals who settled in middle-class neighborhoods. While African Americans and other minority groups received unfavorable perceptions during the post 1960s era, Asian Americans, including South Asians, began surfacing favorably as the model minority (Purkayastha, 2005; Verma, 2008). Media coverage began highlighting the strong academic achievement among the South Asian population. South Asians were applauded for overcoming racial barriers and successfully integrating into American society through their hard work, compliance, and quiet determination. Nevertheless, many still encountered glass ceilings in the workplace and other barriers both socially and professionally.

South Asians from the post 1980s lower socioeconomic subgroup, as well as all South Asians in the post-9/11 political climate, encountered antiimmigration sentiment and racism. The third wave of immigrants were increasingly settling in working class ethnic enclaves and being viewed as the low-skilled "unassimilable foreigner" holding onto backwards traditions (Verma, 2008, p. 6). Their confinement to ethnic enclaves and retention of strong cultural practices has elicited negative societal reception. Ethnic enclaves, such as the India towns in New York City, were viewed from the outside by other Americans "as a form of ethnic separation and a rejection of American civic culture" (Veer, 1995, p. 13). Even the earlier, post-1965 migrants from South Asia harbored disdain for the newer immigrants, as their deviance from the model minority stereotype (marked by low income and lower educational performance) threatened the overall image of South Asians in the US (Bhattacharjee, 2006). In the post-9/11 political climate, South Asians in the US from all immigration waves encountered some degree of prejudice, though the post-1980s lower socioeconomic subgroup experienced the brunt of post-9/11 racism due to their vulnerable economic positions and their ethnic neighborhood settlement. South Asian, Sikh, 
Muslim, and Arab Americans became the targets of numerous hate crimes, employment discrimination, bullying, harassment, and profiling (SAALT, 2012). For example, places of worship were often vandalized and attacked, such as the 2012 shooting of the Sikh gurdwara in Oak Creek, Wisconsin. Several education scholars also addressed the increasing levels of harassment and discrimination towards Muslim and South Asian students since 9/11 (Lee \& Kumashiro, 2005; Ngo, 2006; Verma, 2008).

\section{Co-Ethnic Communities}

Punjabi immigrants from the pre-1965 era initially traveled around California in groups. Facing discrimination from local communities, they settled and found refuge in their own ethnic enclaves, forming strong coethnic communities (Leonard, 1997). These migrants were mostly composed of men, unable to bring their wives and families from India, and denied marriage licenses to marry white women. Thus, over time many of them married local Mexican women because of their cultural similarities and proximity, and formed Punjabi-Mexican bi-ethnic communities in areas such as California's Imperial Valley (southeast) and Yuba City (north). These communities still exist today with descendants of the Punjabi-Mexican pioneers. The bi-ethnic relationships helped early South Asian migrants draw on resources from both their own ethnic communities as well as the Mexican communities.

The post-1965 South Asian immigrants assimilated into middle-class, mostly white suburbs. Since this wave came with more education, professional degrees, and the ability to speak English, they did not need to rely on co-ethnic communities for employment or other resources (Bhattacharya \& Schoppelrey, 2004; Leonard, 1997; Purkayastha, 2005). Many of these immigrants were already equipped with their own human, social, and cultural capital. Despite their dispersed settlement, they still maintained strong ties for other social resources (Purkayastha, 2005).

The subgroup of newer, working-class immigrants settled in urban areas where ethnic enclaves are prominent and growing (e.g., Little Bangladesh in Los Angeles, Little India in Chicago, etc.) (Ingram, 2007; Purkayastha, 2005). Since jobs were not readily available for this group of less qualified immigrants, urban ethnic enclaves provided an initial social and economic 
platform for newly arriving families (Leonard, 1997; Verma, 2008). This tendency to cluster in enclaves demonstrates both strong and weak community characteristics. The social networks may provide an initial platform for newly arriving families; however, paths to upward mobility stagnated due to the drained urban economy, competition for limited jobs, rejection and low acceptance of foreign degrees and qualifications, poverty, surge in anti-immigrant attitudes, and class fractures within immigrant communities (Verma, 2008).

\section{Other Barriers and Opportunities}

Time of arrival clearly determined the types of barriers and opportunities South Asian immigrants faced throughout their three waves of immigration. South Asians arriving at the beginning of the twentieth century found lowskilled jobs right away working the agricultural, lumber, and railroad industries alongside other Asian Americans. However, these immigrants came from peasant backgrounds with low literacy and English speaking abilities, making it hard for them to acculturate in the host society. They encountered a hostile and racist climate with lack of access to civil liberties.

It wasn't until the passage of the 1965 Immigration Act that restrictions were lifted and immigration policies attracted a second wave of skilled Indian, Pakistani and Bangladeshis into professional and technical occupations. This second wave has been characterized as highly educated and arriving in the US with higher socioeconomic status. Individuals from this higher SES background were more familiar with the western educational system and English language due to the effects of British colonial rule, and thus had an easier time assimilating into the US mainstream culture (Leonard, 1997; Purkayastha, 2005).

A subgroup of lower SES migrants (primarily Pakistanis and Bangladeshis) in the third wave faced considerably more barriers than their earlier skilled and educated predecessors. Due to their lower education, rejection of foreign degrees, and lower English abilities, they clung to urban ethnic enclaves for support, but found themselves working in low-wage occupations and facing hardship and anti-immigrant attitudes (Bhattacharya \& Schoppelrey, 2004; Chhaya Community Development Corporation, 2012; 
National Asian Pacific American Community Development Data Center, 2005; Verma, 2008).

As for their location and settlement areas, South Asian Americans continue to be concentrated in metropolitan and coastal areas. These settlement areas are normally considered a positive factor because of their easier access to jobs and co-ethnic networks (Paik et al., 2014). Today, most Indians are upper-class professionals, and they tend to have dispersed settlements in suburban areas. Several Bangladeshi and Pakistani immigrants with generally less skilled professions comprise a mix of dispersed and weak communities in both suburban and urban areas (Bhattacharya \& Schoppelrey, 2004; National Asian Pacific American Community Development Data Center, 2005; Verma, 2008).

\section{Linking Past Immigration Context to Present-Day Social and Educational Outcomes}

Many South Asians in the US today are known to have high socioeconomic and educational outcomes. Census data (2010) show South Asians generally are the highest achieving group in the US with more bachelors and graduate degrees than Whites, Asians, and the overall US population. Many are economically and occupationally successful. Income levels for Indians, for example, surpass the national average and in comparison to other non-Asian and Asian subgroups. However, a closer examination of the group by national origin and immigrant wave reveals nuances in their present-day outcomes. This section highlights the link between government policy, societal reception, co-ethnic communities and other barriers and opportunities that influence present-day economic and educational outcomes for each wave of South Asian immigrants.

As described earlier, the initial wave of South Asian immigrants (mostly Punjabi Sikhs) came with low socioeconomic backgrounds, peasantry skills, limited education and English ability. They were relegated to agricultural, mining, and railroad work and were met with societal prejudice, hostility, and blocked immigration from the US government. In the face of such hostility, the Punjabi Sikhs banded together to form strong co-ethnic communities as support systems. Later they integrated with the MexicanAmerican community by marrying some of their women, and gained access 
to greater resources through these relationships. Through the establishment of family ties with the Mexican Americans, the Punjabi Sikhs found loopholes in government policies that barred them from owning land.

Research on the descendants of this immigration wave is limited. Margaret Gibson $(1987,1988)$ was one of the few scholars to have conducted a study on the population which dated back to the 1980s. Her qualitative case study found that Punjabi Sikhs at the time became entrepreneurial farmers and agriculturalists through hard work and drawing on resources from their co-ethnic communities. Their children faced barriers in American schooling, but nonetheless, fared well in their education. They outperformed both White American and other minority students at the same schools, even though they experienced significant cultural conflict between home and school, little parental school involvement, prejudice, language proficiency problems, and low socioeconomic status. Interviews revealed the Punjabi working-class parents relied heavily on education as a path to socioeconomic mobility for their children.

The Immigrant Act of 1965 welcomed and recruited a second group of South Asians from India, Pakistan and Bangladesh with higher socioeconomic backgrounds and professional skills. With their English language infused by British colonial rule, they did not need to rely on coethnic networks to navigate the host society. They were able to easily enter the American workforce and assimilate into affluent White neighborhoods, now residing primarily in California, New York, New Jersey, and Texas (Leonard, 1997; Purkayastha, 2005; US Census, 2010). While these second wave South Asians earned reputations as the "model minority" - hard workers and high achievers both educationally and professionally - sources say they still encountered different forms of discrimination such as glass ceilings and unfair employment practices. What is unique about this Asian group is that despite their dispersed settlement, South Asians from this and other immigration waves maintained strong ethnic ties to mobilize valuable social resources across the globe. These strong transnational networks with South Asian families in multiple countries is conceptualized as the South Asian diaspora (Leonard, 1997; Purkayastha, 2005).

The high educational attainment, occupation, and income statistics primarily reflect this second immigration wave from South Asia who gained white collar positions as engineers, medical doctors, and scientists, and in 
turn raised their children to follow similar paths. These highly skilled professionals and students continue to immigrate to the US today in large numbers. A significant percentage of international students in US higher education constitute South Asians, particularly from India (Institute of International Education, 2010). The demographic composition of Silicon Valley tech industries also illuminates the continued and growing presence of South Asians in highly professional fields. Table 3 shows that compared to all other Asian subgroups, Indians obtained a much higher percentage $(45 \%)$ of their legal permanent resident status through employment-based preferences in 2010. This indicates that most Indians in the US today are still gaining legal immigration status through their professional skills.

While skilled professionals and students continue to immigrate to the US in large numbers, a particular subgroup of South Asians that differ in immigration experiences and modes of incorporation began arriving since the 1980s alongside the others. Because of this demographic shift that began forming within the South Asian American community, a third immigration wave was noted for this period. New immigration policies, namely the diversity visas and family reunification criteria, began attracting South Asians with fewer professional skills, less education, and lower English ability than their predecessors. Due to low human capital, the newest migrants gravitated to the ethnic neighborhoods in urban America. Today, they work in low-wage occupations and face hardships in the host country with competition for limited jobs, poverty, and anti-immigrant attitudes (Verma, 2008).

It is important to note that Bangladeshis and Pakistanis are the two fastest growing Asian American groups and they mostly immigrated with the 1980's subgroup. Consequently, their demographic characteristics are differing more and more from the Indians. For example, while most Indians obtained legal permanent resident status in the US through employmentbased preferences (Table 3), roughly $75 \%$ of Bangladeshis and $80 \%$ of Pakistanis entered as the immediate relatives of US citizens or under familysponsored preferences. Bangladeshi and Pakistani Americans also tend to be less wealthy than the general Indian American population. Among Asian Americans, Bangladeshis have the second highest poverty rates after Hmong, with about $20 \%$ of Bangladeshis living in poverty (Asian American Center for Advancing Justice, 2011). 
44 Rahman \& Paik - South Asian Immigration \& Education in the U.S.

Table 3

Asian Persons Obtaining Legal Permanent Resident Status by Class of Admissions, 2010

\begin{tabular}{|c|c|c|c|c|c|c|c|c|c|c|c|c|}
\hline \multirow[t]{2}{*}{$\begin{array}{l}\text { Country } \\
\text { of Birth }\end{array}$} & \multicolumn{2}{|c|}{$\begin{array}{c}\text { Family } \\
\text { Sponsored } \\
\text { Preferences }\end{array}$} & \multicolumn{2}{|c|}{$\begin{array}{c}\text { Employment } \\
\text { Based } \\
\text { Preferences }\end{array}$} & \multicolumn{2}{|c|}{$\begin{array}{l}\text { Immediate } \\
\text { Relatives of } \\
\text { US Citizens }\end{array}$} & \multicolumn{2}{|c|}{ Diversity } & \multicolumn{2}{|c|}{$\begin{array}{c}\text { Refugees \& } \\
\text { Asylees }\end{array}$} & \multicolumn{2}{|c|}{ Other } \\
\hline & $\%$ & No. & $\%$ & No. & $\%$ & No. & $\%$ & No. & $\%$ & No. & $\%$ & No. \\
\hline Bangladesh & 41 & 6006 & 6 & 827 & 33 & 4935 & 19 & 2800 & 1 & 171 & 0.5 & 80 \\
\hline Bhutan & $\mathrm{D}$ & & 0 & 6 & 0.5 & 28 & $\mathrm{D}$ & & 99 & 6071 & 0 & 0 \\
\hline Burma & 4 & 459 & 1 & 86 & 5 & 604 & 3 & 329 & 89 & 11445 & 0 & 2 \\
\hline Cambodia & 14 & 418 & 2 & 59 & 76 & 2266 & 4 & 115 & 4 & 113 & 1 & 15 \\
\hline China & 19 & 13610 & 25 & 17949 & 34 & 24198 & 0 & 23 & 21 & 14943 & 0 & 140 \\
\hline Hong Kong & 49 & 1196 & 19 & 464 & 30 & 731 & 1 & 30 & 0 & 7 & 0 & 4 \\
\hline India & 21 & 14636 & 45 & 31118 & 32 & 21831 & 0 & 58 & 2 & 1324 & $\mathbf{0}$ & 195 \\
\hline Indonesia & 10 & 306 & 17 & 515 & 48 & 1461 & 5 & 138 & 19 & 673 & 1 & 39 \\
\hline Japan & 2 & 120 & 32 & 1973 & 63 & 3916 & 4 & 218 & 0 & 12 & 0 & 25 \\
\hline Laos & 9 & 113 & 5 & 59 & 71 & 847 & 0 & 4 & 14 & 172 & 0 & 5 \\
\hline Macau & 59 & 84 & 13 & 18 & 24 & 34 & 5 & 7 & 0 & 0 & 0 & 0 \\
\hline Malaysia & 9 & 149 & 30 & 508 & 41 & 704 & 2 & 40 & 18 & 301 & 0 & 12 \\
\hline Mongolia & 1 & 5 & 11 & 66 & 54 & 320 & 14 & 80 & 20 & 121 & 1 & 2 \\
\hline Nepal & 4 & 269 & 11 & 788 & 18 & 1312 & 23 & 1644 & 44 & 3093 & 0 & 9 \\
\hline
\end{tabular}




\section{HSE - Social and Education History, 5(1)45}

Table 3

Asian Persons Obtaining Legal Permanent Resident Status by Class of Admissions, 2010 (continued)

\begin{tabular}{|c|c|c|c|c|c|c|c|c|c|c|c|c|}
\hline \multirow[t]{2}{*}{$\begin{array}{l}\text { Country } \\
\text { of Birth }\end{array}$} & \multicolumn{2}{|c|}{$\begin{array}{c}\text { Family } \\
\text { Sponsored } \\
\text { Preferences }\end{array}$} & \multicolumn{2}{|c|}{$\begin{array}{c}\text { Employment } \\
\text { Based } \\
\text { Preferences }\end{array}$} & \multicolumn{2}{|c|}{$\begin{array}{l}\text { Immediate } \\
\text { Relatives of } \\
\text { US Citizens }\end{array}$} & \multicolumn{2}{|c|}{ Diversity } & \multicolumn{2}{|c|}{$\begin{array}{c}\text { Refugees \& } \\
\text { Asylees }\end{array}$} & \multicolumn{2}{|c|}{ Other } \\
\hline & $\%$ & No. & $\%$ & No. & $\%$ & No. & $\%$ & No. & $\%$ & No. & $\%$ & No. \\
\hline Pakistan & 34 & 6247 & 16 & 2896 & 47 & 8522 & $\mathbf{0}$ & 14 & 3 & 507 & $\mathbf{0}$ & 72 \\
\hline Philippines & 31 & 17849 & 11 & 6423 & 58 & 33746 & 0 & 14 & 0 & 55 & 0 & 86 \\
\hline Singapore & 8 & 65 & 49 & 377 & 37 & 289 & 2 & 14 & 2 & 18 & 1 & 11 \\
\hline South Korea & 11 & 2351 & 52 & 11642 & 37 & 8128 & 0 & 6 & 0 & 7 & 0 & 93 \\
\hline Sri Lanka & 10 & 195 & 26 & 530 & 32 & 645 & 19 & 394 & 13 & 258 & 1 & 14 \\
\hline Taiwan & 26 & 1722 & 31 & 2090 & 40 & 2691 & 3 & 196 & 0 & 6 & 0 & 20 \\
\hline Thailand & 4 & 345 & 6 & 530 & 44 & 4126 & 1 & 43 & 46 & 4276 & 1 & 64 \\
\hline Vietnam & 59 & 18027 & 1 & 360 & 36 & 11091 & 0 & 0 & 3 & 1032 & 0 & 122 \\
\hline Total & 24 & 84179 & 23 & 79284 & 38 & 132425 & 2 & 6167 & 13 & 44525 & 0.3 & 1010 \\
\hline
\end{tabular}

D = Data withheld to limit disclosure. Source: (Asian American Center for Advancing Justice, 2011) taken from US Department of Homeland Security’s Yearbook of Immigration Statistics, 2010. 
Unfortunately, this subgroup receives little attention from the government and aid policies because their barriers and needs often get lost under the more favorable statistics and reputation of the successful South Asian groups. Immigrants in the third wave are not finding assistance to translate their foreign degrees into skilled work. Their dependence on ethnic enclaves is not as helpful when the more skilled South Asians are not connecting with the less-skilled communities. More and more scholars are starting to notice that children from this subgroup are facing difficulty in schools. Often, the model minority stereotype of South Asians confounds their struggles, as school teachers and even their parents expect them to excel in academics, yet do not have the human capital nor assistance at school to achieve those outcomes (Gibson, 1988; Saran, 2007; Verma, 2008). While educational attainment rates are still high for Bangladeshis, Pakistanis and Indians in the US, the educational outcomes of the third wave subgroup may either be masked under these statistics, or there is a possibility achievement rates may drop in the future.

Finally, a more recent event in the US has affected both immigration policy and societal reception of South Asians across national origin, immigration wave, religion, class, gender and age. The 9/11 attacks with the ensuing "war on terror" has undoubtedly affected the lives of South Asians in the US (Verma, 2008). Journalists and scholars have pointed to a growing fear in the nation towards those who resemble brown-skinned Arabs, resulting in South Asians becoming targets of misguided scrutiny. This has spurred racism, anti-immigrant attitudes, and violence against the South Asian American individuals and communities. Thousands of hate crimes have occurred even to the present day, leaving many South Asians "uneasy" and "scared" (Verma, 2008). Newer immigrants succumb to prolonged waits for visas and permanent residencies due to post $9 / 11$ anti-immigrant legislature. Students in schools are also being targeted with 9/11 racism, and schools have not reacted with appropriate assistance for these students (Lee \& Kumashiro, 2005; Ngo, 2006).

\section{Conclusions and Implications}

This article uses Paik et al.'s (2014) comprehensive model to demonstrate how analysis of the historical context of the South Asian American 
community provides greater understanding of their immigrant experiences and later socioeconomic and educational outcomes. South Asian Americans overall have high educational backgrounds and income levels, but there is diversity even in this group, and unfortunately some needs often go overlooked.

In summary, the majority of South Asians immigrated under favorable or neutral modes of incorporation during the second and third immigration waves. They were wealthy, educated, fluent in English, and had professional skills. Therefore, they did not need government assistance and readily found white collar jobs as engineers, medical doctors, and scientists, and assimilated into white suburban neighborhoods. These immigrants reflect the high educational attainment, occupation, and income statistics. They were indeed vastly different from the earliest predecessors who, small in number, came with several barriers to incorporation, such as low socio-economic background, lack of literacy and English skills, as well as government and societal hostility. Today, these historical Punjabi ethnic enclaves continue to exist, however, little is known about their current educational performance and their group outcomes are trumped in number by the influx of South Asians who arrived after 1965.

Some current third wave immigrants of Bangladeshi and Pakistani origin are not faring as well. Disaggregated data finds that Bangladeshis and Pakistanis have much lower average household incomes than Indians, with almost $20 \%$ of Bangladeshis living in poverty (Asian American Center for Advancing Justice, 2011). Bangladeshis and Pakistanis also tend to immigrate to the US with fewer occupation-ready skills. This subgroup receives little attention from government aid and policies because their needs often get overlooked under the general, more favorable statistics of South Asians. In addition to government support, co-ethnic community members who are more well-established can help the newer immigrants navigate socio-economic institutions in the US.

Additionally, South Asians who reside in urban ethnic enclaves have been known to bear the brunt of $9 / 11$ prejudice and racism. Educational practitioners and policymakers must be aware that the current political climate is particularly difficult for the South Asian community as children in schools are often targets of such prejudice. School practitioners must be vigilant about such incidences and respond appropriately. 
An important lesson that can be learned from examining South Asian immigration experiences is the importance of disaggregating the Asian experience in general. There are about 34 Asian groups and over 300 languages that make up the Asian American demographic (Teranishi et al., 2004). Educational institutions and scholars often lump all Asian groups together in reporting and research, creating a misleading sense of homogeneity (Blair \& Qian, 1998; Fong, 2008; Ngo \& Lee, 2007; Paik et al., 2014). Significant between-group differences exist in the context of immigration, acculturation in the US, and educational and occupational trends. Signs of some progress are evident as some researchers and institutions have begun disaggregating information and research by major subgroups such as "East Asian," "South Asian," and "Southeast Asian". However, it is important to note that diversity within each category also exists and usage of these terms can conceal such distinctions between subethnic groups.

Another lesson gleaned from the case of South Asians is that the "model minority myth" can play a detrimental role in education. Overall, South Asians are still more highly educated than the general US population (Farver, Bhadha, \& Narang, 2002), yet children from the 1980s subgroup struggle because they may not have the family human capital nor assistance at school to achieve the same outcomes (Bhattacharya, 2000; Gibson, 1988; Saran, 2007; Verma, 2008). The model minority stereotype can mask children's educational needs, leaving them unmet (Ngo \& Lee, 2007; Paik et al., 2014), but scholars report that many teachers expect all South Asians to excel in academics. A true understanding of the nature of South Asian immigration experiences should result in a greater awareness and support of the barriers faced by students and their families. Additionally, disaggregation of education data by South Asian subgroups is important. Census data already show that Indians lead South Asians in postsecondary achievement rates, but with the influx of more varied South Asian groups, it is important to see how students in K-12 are performing by ethnic subgroup in terms of education and later economic outcomes.

Understanding the historical context and development of diverse South Asian groups are essential for a better understanding of present-day communities and their resources. The South Asian American experiences over three immigration waves demonstrates the evolvement of immigrant 
families and their co-ethnic communities over time. This historical lens also helps to understand and address current social and educational outcomes of both higher-achieving and lower-achieving South Asian subgroups. It unmasks the educational needs of some groups that have been ignored. These issues bring awareness to the diverse needs and experiences of South Asian students to educators, researchers, and policymakers. Key stakeholders within social, governmental, and educational institutions, as well as in communities where immigrant groups are concentrated, can work together to develop and support community partnerships.

\section{References}

Asian American Center for Advancing Justice. (2011). A Community of Contrasts: Asian Americans in the United States: 2011. Retrieved from http://www.advancingjustice.org/pdf/Community_of_Contrast.pdf Bald, V. (2015). Bengali Harlem and the Lost Histories of South Asian America (Reprint edition). Place of publication not identified: Harvard University Press.

Bhattacharjee, A. (2006). The Public/Private Mirage: Mapping Homes and Undomesticating Violence Work in the South Asian Immigrant Community. In A. Sharma \& A. Gupta (Eds.), The Anthropology of the State (pp. 337-355). Malden, MA: Blackwell Publishing.

Bhattacharya, G. (2000). The school adjustment of South Asian immigrant children in the United States. Adolescence, 35, 77-85. Retrieved from https://www.ncbi.nlm.nih.gov/pubmed/10841298

Bhattacharya, G., \& Schoppelrey, S. L. (2004). Preimmigration beliefs of life success, postimmigration experience, and acculturative stress: South Asian immigrants in the United States. Journal of Immigrant Health, 6(2), 83-92. doi: https://doi.org/10.1023/B:JOIH.0000019168.75062.36 Blair, S. L., \& Qian, Z. (1998). Family and Asian students' educational performance: A consideration of diversity. Journal of Family Issues, 19, 355-374. doi: 10.1177/019251398019004001

Chhaya Community Development Corporation. (2012, March 6). Deepening roots and creating space: Building a better future for New York's South Asians. Retrieved from http://www.chhayacdc.org/ourissues.html 
50 Rahman \& Paik - South Asian Immigration \& Education in the U.S.

Farver, J. A. M., Bhadha, B. R., \& Narang, S. K. (2002). Acculturation and psychological functioning in Asian Indian adolescents. Social

Development, 11, 12-29. doi: 10.1111/1467-9507.00184

Fong, T. P. (2008). The contemporary Asian American experience: Beyond the model minority (3rd ed.). Upper Saddle River, NJ: Pearson Prentice Hall.

Gibson, M. A. (1987). The school performance of immigrant minorities: A comparative view. Anthropology and Education Quarterly, 18, 262-275. doi: 10.1525/aeq.1987.18.4.04x0018

Gibson, M. A. (1988). Accommodation Without Assimilation: Sikh Immigrants in an American High School. Cornell University Press. Ingram, S. (2007). South Asian Americans. Milwaukee, WI: World Almanac Library.

Institute of International Education. (2010). Open Doors 2010 Report. Retrieved from http://www.iie.org/en/Research-and-Publications/OpenDoors

Kao, G. (1995). Asian Americans as model minorities? A look at their academic performance. American Journal of Education, 103, 121-159. Retrieved from https://www.jstor.org/stable/1085574?seq=1 page_scan_tab_contents

Lee, S. J., \& Kumashiro, K. K. (2005). A Report on the Status of Asian Americans and Pacific Islanders in Education: Beyond the "Model Minority" Stereotype. National Educational Association.

Leonard, K. I. (1997). The South Asian Americans. Connecticut: Greenwood Press.

National Asian Pacific American Community Development Data Center. (2005). South Asian Demographic Analysis. Retrieved from southasianforum.org/pdfs/Census_Fact_Sheet.pdf

Ngo, B. (2006). Learning from the margins: The education of Southeast and South Asian Americans in context. Race, Ethnicity and Education, 9, 5165. doi: 10.1080/13613320500490721

Ngo, B., \& Lee, S. J. (2007). Complicating the image of model minority success: A review of Southeast Asian American education. Review of Educational Research, 77(4), 415-453. doi:10.3102/0034654307309918

Paik, S. J., Kula, S. M., Saito, L. E., Rahman, Z., \& Witenstein, M. A. (2014). Historical perspectives on diverse Asian American communities: 


\section{HSE - Social and Education History, 5(1)51}

Immigration, incorporation, and education. Teachers College Record, 116(8). Retrieved from

http://www.tcrecord.org/library/abstract.asp?contentid=17512

Pew Research Center. (2012). The rise of Asian Americans. Washington,

DC: Pew Social \& Demographics Trends. Retrieved from

http://www.pewsocialtrends.org/files/2012/06/SDT-The-Rise-of-AsianAmericans-Full-Report.pdf

Portes, A., \& Rumbaut, R. G. (1990). Immigrant America: A portrait.

Berkeley, CA: University of California Press.

Portes, A., \& Rumbaut, R. G. (2001). Legacies: The story of the immigrant second generation. (Ewing, NJ). University of California Press.

Retrieved from http://psycnet.apa.org.ccl.idm.oclc.org/psycinfo/199510914-001

Purkayastha, B. (2005). Negotiating ethnicity: Second-generation South Asian Americans traverse a transnational world. USA: Library of Congress.

SAALT. (2012). A demographic snapshot of South Asians in the United States. Retrieved from http://www.saalt.org/pages/About-the-SouthAsian-Community.htm

Sakamoto, A., Goyette, K., \& Kim, C. H. (2009). Socioeconomic attainments of Asian Americans. Annual Review of Sociology, 31(4), 255-276. doi:10.1146/annurev-soc-070308-115958

Sandhu, D. S., \& Madathil, J. (2008). South Asian Americans. In Culturally alert counseling: a comprehensive introduction (Vol. 1, pp. 353-388).

California: Sage Publications, Inc.

Saran, R. (2007). Model minority imaging in New York: The situation with second generation Asian Indian learners in middle and secondary schools. Anthropologist Special Issue, 2, 67-79.

South Asian Network. (2016). Historical Context of Organizing South Asians. Retrieved from http://southasiannetwork.org/about/historicalcontext-of-organizing-south-asians/

Teranishi, R. T., Ceja, M., Antonio, A. L., Allen, W. R., \& McDonough, P. M. (2004). The college-choice process for Asian Pacific Americans: Ethnicity and socioeconomic class in context. Review of Higher Education, 27(4), 527-551. doi: 10.1353/rhe.2004.0025 
52 Rahman \& Paik - South Asian Immigration \& Education in the U.S.

US Census. (2010). Profile of General Population and Housing Characteristics: 2010 Demographic Profile Data. Washington, DC: United States Census Bureau. Retrieved from http://factfinder2.census.gov/faces/tableservices/jsf/pages/productview.xh tml?pid=DEC_10_DP_DPDP1\&prodType=table

US Government Accountability Office. (2007). Higher education:

Information sharing could help institutions identify and address challenges that some Asian American and Pacific Islander students face. Retrieved from http://www.gao.gov

Vartanian, T. P., Karen, D., Buck, P. W., \& Cadge, W. (2007). Early factors leading to college graduation for Asians and non-Asians in the United States. The Sociological Quarterly, 48, 165-197. doi: 10.1111/j.15338525.2007.00075.x

Veer, P. van der. (1995). Nation and Migration: The Politics of Space in the South Asian Diaspora. University of Pennsylvania Press.

Verma, R. (2008). Backlash: South Asian immigrant voices on the margins. Rotterdam, Netherlands: Sense Publishers.

Wright, W. E. (2007). Heritage language programs in an era of English-only and No Child Left Behind. Heritage Language Journal, 5(1), 1-26.

Retrieved from https://eric.ed.gov/?id=EJ831190

Xie, Y., \& Goyette, K. (2003). Social mobility and the educational choices of Asian Americans. Social Science Research, 32(467-498). doi:

10.1016/S0049-089X(03)00018-8

Zaynah Rahman: Research Associate. School of Educational Studies. Claremont Graduate University (United States)

Susan J. Paik: Associate Professor. School of Educational Studies. Claremont Graduate University (United States).

Contact Address: zaynah.rahman@gmail.com, susan.paik@cgu.edu 